\title{
Chapter 10 \\ Loneliness in Children Adapting to Dual Family Life
}

\author{
Inge Pasteels and Kim Bastaits
}

\section{Introduction}

In 2005, Belgium was among the frontrunners in terms of European divorce statistics, with a crude divorce rate of 2.9 per 1000 of the population (Eurostat 2015). The current rate of divorce in Belgium is lower, but this change is mainly due to a higher prevalence of unmarried cohabitation instead of marriage, and to selection effects for more recent marriage cohorts. Thus, the number of relationship break-ups has not decreased. Instead, there has been a shift away from high rates of divorce and toward high rates of separation, especially given that unmarried cohabitations are more likely to break up than marriages. Survey data for Flanders (the northern Dutch-speaking region of Belgium) from the Generations and Gender Programme (Neels et al. 2011) shows that by the age of 45, three out of ten men and four out of ten women had experienced a relationship break-up in the form of either a divorce or a separation (Pasteels et al. 2013). At the same time, unmarried cohabitation has become an acceptable context for bringing up children in Belgium. This evolution has accelerated in recent decades. The proportion of children born to unmarried parents in Belgium increased from 28\% in 2000 to 51\% in 2015 (ADSEI 2018). Although the statistics show a decrease in the number of divorces, these trends clearly suggest that a substantial percentage of children experience a parental relationship break-up. Lodewijckx (2005) calculated for 2004 that more than $20 \%$ of all Flemish children under age 18 had experienced a parental divorce. More recently, Pasteels (2012) calculated that the average number of children involved in each divorce is 1.1 . This equates to 25,365 children experiencing a parental divorce in 2017 in Belgium (ADSEI 2018). However, this figure is an underestimation of the total number of children experiencing a parental relationship break-up, as the

I. Pasteels $(\bowtie) \cdot$ K. Bastaits

PXL University of Applied Sciences and Arts, Hasselt, Belgium

e-mail: inge.pasteels@pxl.be 
proportion of children with separated parents has been increasing, and is expected to rise in the near future.

Parent-child relationships after divorce or separation develop in the context of single-parent families or new family structures formed through repartnering. Divorce or separation is not an endpoint in a parent's relationship trajectory. Due to repartnering dynamics, a single-parent family can turn into a different kind of family. For Flanders, Audenaert (2018) calculated that two out of ten families with at least one child younger than age 25 living in the household are single-parent families, and that one out of ten of these families is "newly composed," meaning that a parent co-resides with a new partner (and possibly his or her children). A previous Flemish study by Pasteels and Mortelmans (2013) showed that $20 \%$ of men and women who divorced between 2001 and 2005 had already begun a relationship with a new partner before leaving the marital home. Two years after living separately from the ex-spouse, 30\% of fathers and mothers were living with a new partner, usually in an unmarried cohabitation. Second marriages are rare, and fewer than one in five parents had remarried within 5 years of a divorce. However, newly composed families are common. Four out of ten divorcees were cohabiting with a new partner and at least one child in the household, and one out of ten divorcees (14\% of men and $12 \%$ of women) were living in a family with biological children and stepchildren. From a child's perspective, one out of four young adults whose parents divorced 20 years previously experienced a second relationship break-up on the mother's or the father's side (Pasteels and Mortelmans 2013).

A relationship break-up - whether in the form of a divorce or a separation - can be considered a complete transition for all of the individuals involved (Amato 2000). Research on the well-being of children after divorce clearly shows that their development can be damaged by the turbulence in their family life (Amato and Keith 1991), but that having satisfying parent-child relationships can mitigate the detrimental effects caused by the divorce itself (Amato and Gillbreth 1999). Overall, researchers agree that a lack of parental communication and the presence of parental conflict are the most damaging factors, and can have a huge impact on a child's well-being after divorce or separation (Amato 2000; Lansford 2009). Accordingly, Belgian divorce law, which is considered to be among the world's most progressive legal frameworks for marital dissolution, changed significantly in 1995 and in 2006. To discourage high-conflict divorces and to encourage positive parent-child relationships, Belgian lawmakers implemented two important legal changes aimed at ensuring continuous ties between parents and children. First, the Act of 13 April 1995 introduced the principle of the joint exercise of parental authority over the person and the property of children after divorce. Second, to facilitate proper parentchild bonds with both parents and to reduce the number of physical custody battles, the Act of 18 July 2006 introduced joint physical custody. Under this law, joint physical custody has to be considered prior to any other residence options if one of the parents requests this arrangement, or if the parents do not indicate any preference regarding the post-marital living arrangements for their children. The intention of the legislation is to improve the well-being of children after their parents divorce by increasing the frequency of their contact with both parents. 
This chapter contributes to the literature on children's well-being after divorce by taking a child's perspective on family formation and family dissolution. To perform an in-depth investigation of the impact of divorce or separation on children, it is essential to consider the characteristics of the new family life a child experiences after a relationship break-up, which we refer to here as "dual family life." We strongly believe that after a divorce, the children have to be flexible and adaptive in order to adjust to a dual family life, as they become members of two families.

Children are supposed to be "flexible" after parental divorce or separation. Following the relationship break-up, they continue their childhood while living in two households. Decisions about their living arrangements, which are made by their parents or dictated by a judge, determine how much time the children will spend in the mother's and the father's household, and how many times per month the children will move between the two households. Children are expected to be flexible, which in this case means that they have to be prepared to live in two households and to be strong enough to handle the stress of frequently moving between them. In addition, each household may have its own rules and regulations based on the parents' own norms and beliefs about raising children. Children must adjust to the respective household in order to avoid conflicts with family members in daily life. This can be considered yet another way in which children are expected to be flexible after their parents' divorce. Moreover, the composition of each household can differ from day to day or week to week, as (step)siblings might also live all or part of the time in the same household. If the living arrangements differ for children and their (step)siblings, they are continuously confronted with a varying family constellations, because all of the children spend part of their time in the household of their parent and stepparent. This can result in children and their (step)siblings having common (step)parent-child activities, but also in each child spending time solely with his/her own parents and stepparents. The parental behavior of the children's own parents and of their stepparents might change if (step)siblings are present. Accordingly, children have to be flexible enough to adjust to a changing structure (constellation) and a changing culture (norms and beliefs) because of differences between the households of the mother and the father, and possibly because of continuous changes in each of these households.

Moreover, children are supposed to be "adaptive" after a parental divorce or separation. The concept of adaptive families refers to the family transitions that occur in the mother's or the father's household, and is also known as the multitransitions perspective (Amato 2010). Due to repartnering dynamics, family constellations can change over time, and such changes can happen more than once, and on both the mother's and the father's side. Children accompany their parents on their relationship trajectories. Thus, if a child is co-residing with a parent, s/he experiences each start or end of a relationship as a new family transition that changes the family composition in the household. The start of a cohabiting relationship means that a stepparent and, in some cases, stepsiblings enter the household. When a marriage or an unmarried cohabitation dissolves, a stepfamily can disappear from the child's household, and even out of his/her life. The child only undergoes these transitions because adults have made decisions about their relationships. After each 
family transition, the parent-child relationships have to be re-balanced within the new family structures.

In the current study, we elaborate on the idea that after a parental divorce or separation, children live in adaptive and flexible families, and are forced by the circumstances of the divorce to adjust to a so-called dual family life. This adjustment can be more or less successful. On the one hand, having a dual family life can contribute positively to the social and emotional well-being of a child by adding to the richness of his/her ties and bonds, and by serving as a source of opportunities to improve his/ her social, cultural, and economic capital. On the other hand, if a child finds adapting to a dual family life very difficult, s/he risks losing the attachment to his/her family in general, and to his/her parents in particular. Since the feeling of belonging permanently to one unique family or household is lacking, the child may experience loneliness. The child is likely to feel lonely especially if s/he does not subjectively experience his/her parent-child ties as warm and tender; or if the child observes that his/her parents are less supportive or less involved in his/her life than they were when they were still married.

Loneliness is an understudied indicator of children's well-being after divorce, and research into loneliness in children did not start to appear until the 1980s and 1990s. Prior to that time, loneliness in children was not seen as an independent area of research, as there was a belief that children did not experience strong feelings of loneliness (Bullock 1993). Studies in which loneliness was reliably measured in kindergarten and primary schools found that the concept of loneliness had meaning for young children, and could be considered similar to the feeling experienced by older children and adults (Cassidy and Asher 1992; Ladd et al. 1996). Recent studies have shown that one out of five children aged seven to twelve say they are lonely sometimes or often (Qualter et al. 2015), and that four out of five adolescents have experienced feelings of loneliness at some point in time, with one-third describing these feelings as persistent and painful (Houghton et al. 2016). Research on psychological well-being has provided empirical evidence for the association between loneliness during adolescence and the prevalence of depressive feelings (Koenig et al. 1994; Lau et al. 1999). Other studies have shown that loneliness is of major importance as a predictor of life satisfaction in later life (Chipuer et al. 2003; Neto 1993). More recently, Qualter et al. (2010) found that long-lasting peer-related loneliness during childhood acts as an interpersonal stressor that predisposes children to have depressive symptoms in adolescence. Although many studies about children's feelings of loneliness have been conducted in educational settings, teachers and other professionals who interact with children have mentioned several factors that occur outside of the school context as possibly contributing to children's feelings of loneliness, such as family conflict, moving to a new school or neighborhood, losing friends or pets, experiencing the divorce of parents, or experiencing the death of a significant person. We can certainly imagine that the impact of these factors will be increased if they occur simultaneously, as is likely to be the case in the context of a parental divorce.

Based on these observations, we explore how the characteristics of dual family life affects children's feelings of loneliness after a parental divorce. In particular, we 
examine how the structural characteristics of dual family life influence feelings of loneliness in children after a divorce. The main structural characteristics we consider are the child's living arrangements, the number of family transitions s/he experiences, and the presence of a stepparent in the household of either the mother or the father. These structural characteristics model a child's family life after a parental divorce as a framework within which parent-child relationships are continued and shaped. The number of family transitions a child experiences indicates the level of adaptation that is expected of the child after a divorce; the child's living arrangements reflect the level of flexibility that is required of the child after a divorce; and the presence of a stepparent indicates the levels of adaptation and flexibility that are demanded of the child in the context of a dual family life.

The contribution of the current study is threefold. First, the existing research on loneliness within the family context is sparse. This study adds to our scientific knowledge of children's feelings of loneliness after divorce by exploring the link between these feelings and the aforementioned structural components of dual family life using a gender-inclusive framework in which information about both the maternal and the paternal relationship trajectory of the child is included. Second, examining the complexity of the dual family life that children of divorced or separated parents are dealing with can help professionals who interact with children understand the impact these turbulent family trajectories might have on these children. Third, in the context of policy evaluation research, it is important to gain insights into the mechanisms that underlie children's well-being after divorce in order to provide accurate information to policy-makers and legislators considering future policy measures.

\section{Literature Review}

\section{Theoretical Considerations}

There are different theoretical approaches to the relationship between dual family life and children's well-being. First, the divorce-stress-adjustment perspective (Amato 2000) suggests that divorce and the subsequent transitions a family might undergo are stressful events that decrease the well-being of all the individuals involved. Second, there is the economic hardship perspective (Amato 1993). This theoretical framework posits that economic resources are greater in households with two cohabiting partners than in single-parent households because of a loss of scale advantages in the latter. Consequently, the reduction in economic resources due to a relationship dissolution might negatively influence a child's well-being, whereas starting a new relationship could lead to a recuperation of lost economic resources, and, in turn, to an increase in the well-being of the children (Amato 2000; Lansford 2009; Leon 2003). A third theoretical approach is the parental resource theory (Thomson and McLanahan 2012; Thomson et al. 1994). In addition to providing 
economic resources, parents should spend time with their children in order to be involved in their lives. Parental involvement is of major importance for a child's well-being, as the Flemish study by Bastaits et al. showed (2014). From the viewpoint of the parental resource theory, the presence of a stepparent as a second adult in the household in addition to the biological parent can have a different meaning than the two biological parents living together. The economic hardship perspective, by contrast, treats these two family structures as equivalent. In the parental resource framework, examining the quality of (step)parent-child relations and the quality of (ex-)partner relations in different family constellations can be helpful when seeking to understand the subjective experiences of parental resources in specific family structures. In line with the stress-related theory of Amato (2000), the instability hypothesis proposed by Fomby and Cherlin (2007) offers the relatively straightforward suggestion that children who experience multiple family transitions may fare worse developmentally. The economic hardship perspective and the parental resource theory are more ambiguous, as they argue that transitions can have different meanings when different types of resources are available, and that the effects of these transitions on children's well-being might vary. We label this overall perspective as the change hypothesis, which states that changing family structures can positively or negatively affect children's well-being depending on increasing or decreasing resources.

\section{Prior Findings}

There are only a few previous studies on the impact of a parental divorce or of the characteristics of post-divorce family life on loneliness in children. The effects of family characteristics were studied by Quay (1992), who found that living in a single-parent or a stepparent family increases a child's loneliness. Brage et al. (1993) reported that family effectiveness and communication between mothers and adolescents are negatively related to loneliness. Rotenberg (1999) emphasized the link between loneliness in children and perceived levels of parental warmth and parental involvement, but also pointed out that the effects differ between children and adolescents. Similarly, Civitci et al. (2009) found that adolescents with divorced parents are more susceptible to loneliness than adolescents with non-divorced parents.

There are, however, numerous studies on the effects of joint physical custody as a specific post-divorce living arrangement for children, and on the effects of the number of) post-marital family transitions and the presence of a stepparent in the parent's household on other indicators of the well-being of children. Since the introduction of joint physical custody options, many researchers have focused on the effects of such arrangements on the well-being of children. Systematic literature overviews have been provided by Bauserman (2002, 2012), Nielsen (2011, 2013, 2014, 2015a, b, 2017), and Baude et al. (2016). In a study that focused on the fatherchild relationship, Bauserman (2012) found that children in joint physical custody 
arrangements have more qualitative father-child relationships, and that their fathers are more involved than those of children in sole custody arrangements. The metaanalysis by Baude et al. (2016) showed no significant differences between children in joint physical custody and sole (maternal) custody arrangements. Nielsen (2014) conducted a literature review of research on custodial arrangements and concluded that children living in joint physical custody arrangements have better relationships with their parents than those living in sole maternal custody arrangements. For Flanders, the findings of a recent study by Bastaits and Pasteels (2019) indicated that compared with sole custody (by either the mother or father), joint physical custody provides a better framework for shaping the child's relationships with both parents, as it facilitates open communication and mutual support.

With regard to family structure and family transitions, many empirical studies have shown that children living in a single-parent family or a stepfamily are at greater risk of experiencing a decreased level of well-being (for an overview, see Amato 2000; Lansford 2009). Studies that focus on family structure transitions have been carried out by Langton and Berger (2011), Lee and McLanahan (2015), Magnuson and Berger (2009), Robson (2010), and Ryan et al. (2015). Langton and Berger (2011) examined the associations between the family structure and the physical health, behavior, and emotional well-being of adolescents. Their results suggest that adolescents in two-biological-parent families tend to have better outcomes than those in most other family types. Lee and McLanahan (2015) concluded that the transition out of a two-parent family is more negative for a child's development than the transition into a two-parent family. Magnuson and Berger (2009) demonstrated that family structure transitions are associated with increases in behavioral problems, and are marginally associated with decreases in achievement. Robson (2010) showed that transitioning out of a two-parent biological family is associated with reduced happiness, self-esteem, and household income; and that transitioning into a stepfamily is also associated with decreased happiness, even when it is accompanied by an increase in household income. Ryan et al. (2015) found that changes in family structure that occurred early in life - particularly transitions from a twobiological-parent to a single-parent family - predicted increases in behavioral problems. Their findings also indicated that transitioning into a single or a stepparent family mattered more for children of higher-income than lower-income parents; and that for children of higher-income parents, moving into a stepfamily might improve, rather than undermine, behavior. For Flanders, Bastaits et al. (2018) recently found that the well-being of adolescents was lower if their mother was in a less stable partnership situation: i.e., if their mother had never repartnered, was in a LAT (living apart together) relationship, or had been in several relationships since her divorce. The opposite result was found for fathers, as the adolescents' well-being was shown to be lower if their father was in a seemingly stable partnership situation; i.e., if their father had remarried or started living with a new partner since his divorce. 


\section{Hypotheses}

In this study, we contribute to our existing knowledge by testing the instability hypothesis and the change hypothesis while taking into account three post-divorce family characteristics: the number of family transitions, the presence of a stepparent in the household, and the living arrangements of the children. Since the dual family life experienced by children is the general context of this study, the tests are carried out simultaneously from the father's and the mother's perspective in each model. Based on the previous literature and theoretical frameworks, we propose a set of research hypotheses regarding the loneliness, the flexibility, and the adaptive behavior of children after a parental divorce:

- In line with the instability hypothesis, we expect to find that a greater number of maternal or paternal family transitions is linked to accumulated stress, and therefore leads to increased feelings of loneliness in children (hypothesis 1a).

- Based on the change hypothesis, we do not expect to find that the number of transitions influences a child's loneliness levels, since the current amount of economic and paternal resources may be more important than the number of family transitions experienced in the child's life course (hypothesis $1 \mathrm{~b}$ ).

- In line with the instability hypothesis, we expect to find that the child's level of loneliness increases if a stepparent lives in the household of a parent (either the biological mother or father), since repartnering is a new family transition that can be a stressful experience (hypothesis $2 \mathrm{a}$ ).

- Based on the change hypothesis, we assume that the amount of economic and parental resources in a family determines the impact of a co-residing stepparent on the well-being of the children, and that this effect can be positive or negative. Since mothers tend to lose more economic scale advantages than fathers, we might expect to observe that the positive effect on children's well-being is stronger if the biological mother repartners. At the same time, we know from previous Flemish research that repartnered fathers are more likely than repartnered mothers to live in a household with stepchildren (Pasteels and Mortelmans 2013). This means that in a household with a repartnered mother, the parental resources will be more likely to benefit the mother's biological child or children. Thus, the negative impact of the presence of a stepparent on the parent-child relationship is likely to be smaller in such a household than in the household of a repartnered father, in which the parental resources are more likely to be shared between stepsiblings. This leads us to formulate the second competing hypothesis: i.e., that the effect of the presence of a stepparent in the household is more positive if the repartnered parent is the mother, and that it decreases feelings of loneliness in children (hypothesis 2b).

- Finally, we explore the effects of living in a joint physical custody on the wellbeing of children. Based on the instability hypothesis, we expect to find that children who commute between two parental households are at higher risk of experiencing feelings of loneliness (hypothesis $3 a$ ). 
- However, in line with the change hypothesis, we anticipate that the risk of feeling lonely will be lower for these children because shared residence arrangements are more common in families with greater economic resources, and in which the two parents have equal amounts of time to spend with their children (hypothesis 3b).

\section{Methods and Data}

\section{Data}

We use data from the multi-actor study "Divorce in Flanders" (DiF) that were collected in 2009 and 2010 by interviewing 6470 (ex-)partners and 1257 children via Computer Assisted Personal Interviews (CAPI). The multi-actor design involved criteria used to select one child (if there were any) for each reference marriage (Mortelmans et al. 2011; Pasteels et al. 2011). For the current study, a subsample of 166 children from 166 broken marriages was selected. Our selection criteria were the age of the child, the living arrangements of the child, and the survey participation of both parents. The age range of the children included in the sample was between ten and 17, because only children in this age group answered specific questions about loneliness. Moreover, the children selected for the sample had been living with at least one of their parents at the time of the interview to allow for comparisons between children living in joint physical custody arrangements and children who were living with either their mother or their father most of the time. The participation in the survey of both parents was necessary to allow us to obtain information about their partnership status at the time of the interview and their relationship trajectory to that point. Based on these selection criteria, the analytical sample contains triadic data for 166 children and both of their parents. Since only the first marriages of heterosexual couples were selected in the DiF study, the parents can always be referred to as the mother and the father.

\section{Variables}

The dependent variable included in the analysis is the LLCA peers subscale, which measures children's feelings of loneliness by using 12 items (Goossens and Marcoen 1999).

- I think I have fewer friends than others

- I feel isolated from other people/I feel I don't belong

- I feel excluded by my classmates

- I want to be better integrated in the class group

- Making friends is hard for me 


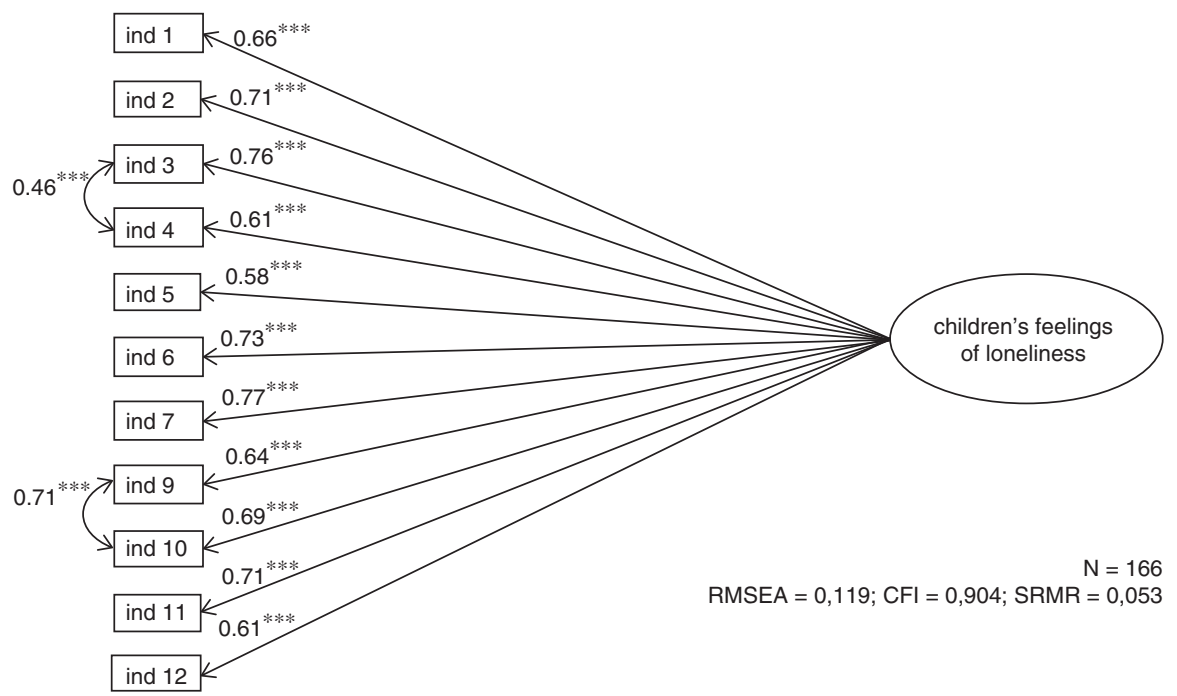

Fig. 10.1 Measurement model for the latent construct of children's feelings of loneliness

- I am afraid the others won't let me join in

- I feel alone at school

- I do not think there is any one friend I can tell everything to

- I feel abandoned by my friends

- I feel left out by my friends

- I feel sad because nobody wants to join in with me

- I feel sad because I have no friends

The children had to indicate on a four-point scale (often, sometimes, rarely, never) how often these statements applied to them. In line with the finding mentioned above that children's loneliness can be measured by using a single-factor structure, a confirmatory factor analysis on the LLCA peers subscale identified a single factor with factor loadings between 0.58 and 0.77 for our analytical sample. In order to improve the fit of this measurement, item eight was excluded from the measurement model and error variances were freed between two pairs of indicators. Items three and four on the one hand and items nine and ten on the other are worded very similarly in Dutch. The goodness of fit statistics show an adequate fit with $\mathrm{CF}=0.904$ and $\mathrm{SRMR}=0.053$, as these statistics are greater than 0.9 and less than 0.08 , respectively (Brown 2006). The RMSEA of 0.119 is above the cut-off of 0.08 , but this goodness of fit indicator may be of minor importance given the small sample size ( $\mathrm{N}=166)$, as $\mathrm{Hu}$ and Bentler (1999) have suggested. The single factor structure is in line with previous research. Recently, a Belgian study that employed the widely used measurement of children's feelings of loneliness developed by Asher et al. (1984), the Children's Loneliness Scale (CLS), showed that a single-factor structure is superior to alternative solutions proposed in the literature as a valid measurement of loneliness in children (Maes et al. 2017) (Fig. 10.1). 
There are three main independent variables. First, there is a measurement of the living arrangements of the child that uses a monthly calendar (Sodermans et al. 2012). Based on the patterns indicated in this calendar by the mother (or father, if the information from the mother was lacking), we created a dummy variable containing information about the living arrangements of the child; i.e., whether the child was in a joint physical custody arrangement. If the proportions of time spent with the mother and with the father were each between $33 \%$ and $66 \%$, we categorized the living arrangement as joint physical custody, and scored the dummy variable as one. If the time spent with the mother (father) was more than $66 \%$, and, consequently, the time spent with the father (mother) was less than $33 \%$, the dummy variable was given a score of zero. In addition to the living arrangements of the child, we also considered for both parents the current partnership status and the partnership trajectory up to the time of the interview.

The current partnership status was recoded as a dummy variable, with one indicating that the parent had a co-residential new partner after divorce, and zero indicating that the mother or father was living as a single parent without a new co-residing partner. Information about the partnership histories of both parents was included in the model by using the number of partnership transitions for both parents that the child had experienced. The number of transitions was deduced from the previously published partnership history clusters (Pasteels and Mortelmans 2015). Divorcees who remained single or were only in a LAT relationship after their divorce were classified as having been involved in one transition only. The children of divorcees who remarried or started cohabiting with a new partner after a short or a long period of being single were categorized as having experienced two transitions in the household of either their mother or father. If there was a relationship in the post-marital trajectory that subsequently broke up, resulting in three transitions and multiple relationships after divorce, the number of transitions was recoded as four or more transitions in the mother's or the father's household. The control variables included in the model were the age of the child, the gender of the child, and the educational level of the mother and the father (Table 10.1).

\section{Analytical Strategy}

We estimated structural equation models (SEM) for the indicator of loneliness in order to investigate the effects of living in a joint physical custody arrangements and the characteristics of the partnership trajectories of both parents on the child's feelings of loneliness, controlled for the age and the gender of the child and the educational level of the mother and the father. Statistical analyses were conducted with Mplus 6 software (Muthén and Muthén 2010), using ML estimation. 
Table 10.1 Descriptive statistics

\begin{tabular}{l|l|l}
\hline & Mean & Standard deviation \\
\hline Number of maternal family transitions & 1.86 & 0.92 \\
\hline Number of paternal family transitions & 2.07 & 1.16 \\
\hline Age of child & 13.74 & 2.14 \\
\hline Living arrangements & Column percent & \\
\hline Joint physical custody & & \\
\hline Other arrangement & 60.8 & \\
\hline New partner of father & 39.2 & \\
\hline Not living with a new partner & & \\
\hline Living with a new partner & 43.5 & \\
\hline New partner of mother & 56.5 & \\
\hline Not living with a new partner & & \\
\hline Living with a new partner & 53.0 & \\
\hline Gender of child & 47.0 & \\
\hline Boy & & \\
\hline Girl & 53.6 & \\
\hline Educational level of father & 46.4 & \\
\hline Lower-secondary or below & & \\
\hline Upper-secondary & 25.0 & \\
\hline Higher education & 40.5 & \\
\hline Educational level of mother & 34.5 & \\
\hline Lower-secondary or below & & \\
\hline Upper-secondary & 16.1 & \\
\hline Higher education & 38.1 & \\
\hline & 45.8 & \\
\hline
\end{tabular}

\section{Results}

The structural model for the child's feelings of loneliness related to the characteristics of dual family life is presented in Fig. 10.2. This model reveals a good fit $(\mathrm{RMSEA}=0.055 ; \mathrm{CFI}=0.907 ; \mathrm{SRMR}=0.042)$. This structural equation model clearly shows that the child's feelings of loneliness are significantly and positively linked with two different characteristics of dual family life, at the $\left.\mathrm{p}<0.01{ }^{(* *}\right)$ and $\mathrm{p}<0.05\left(^{*}\right)$ level. For the father, the number of paternal family transitions $(0.11)$ influences the child's feelings of loneliness, with a greater number of family transitions in the father's household leading to increased feelings of loneliness for the child. The father's current partnership status, measured by a dummy variable that indicates whether a new partner is living in the household, has no impact on the child's loneliness. For the mother, the structural equation model reveals the opposite pattern. If the mother and her new partner are co-residing, the child has greater feelings of loneliness than if the mother is single or in a LAT relationship (0.22). The number of family transitions that occur in a maternal household has no impact on the dependent variable. The living arrangements of the child is found to have no 


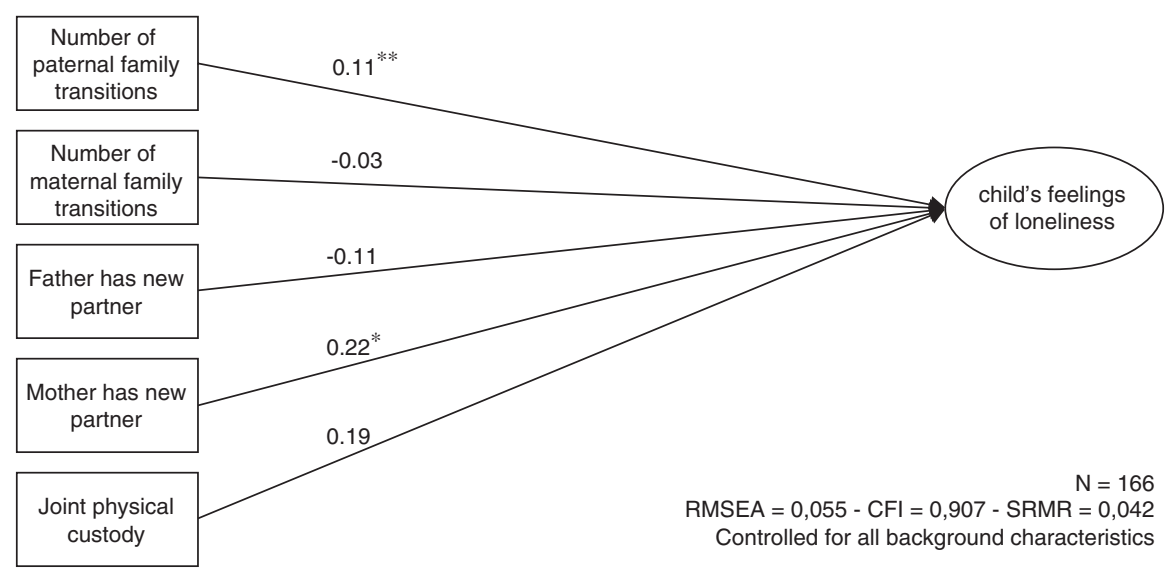

Fig. 10.2 Structural model for children's feelings of loneliness related to the characteristics of dual family life

effect: i.e., living in a joint physical custody arrangement, rather than living primarily with the mother or the father, does not appear to influence the child's feelings of loneliness. The effects of the main independent variables are controlled for the age and the gender of the child and the educational levels of both parents. None of these control variables has a significant effect on the child's feelings of loneliness.

\section{Discussion}

In this study, we explored children's feelings of loneliness when adapting to dual family life. The first perspective on the impact of dual family life suggests that children living in joint custody arrangements, as well as children with one or more subsequent stepparents in their family network on either their mother's or their father's side, experience less loneliness. This is assumed to be case because these children may have the subjective feeling of being strongly embedded in their parents' households, or they may forge family ties with multiple people and have increased opportunities to acquire social, cultural, and economic capital. The competing perspective suggests that children living in joint custody arrangements or in newly composed families, including stepfamilies, experience greater feelings of loneliness because a dual family life demands high levels of flexibility and adaptation, and may lead to the loss of their closest emotional bonds.

Using triadic data for 166 children and their mothers and fathers collected in the Divorce in Flanders study, we found that the number of post-divorce family transitions in the household of the father predicts the child's feelings of loneliness. If the father had multiple relationships after his divorce, or had another relationship breakup after the initial divorce, the child's feelings of loneliness were increased. This 
finding is in line with the instability hypothesis, which states that unstable family structures lead to decreased well-being (hypothesis 1a). By contrast, the number of family transitions in the mother's household was found to have no effect, which means that the change hypothesis (hypothesis $1 \mathrm{~b}$ ) concerning the effects of family transitions on feelings of loneliness in children was confirmed for the mother's side. It appears that the increase in resources associated with a maternal family transition was more important than the number of family transitions in the household.

As a post-marital relationship with a co-residing stepmother was not found to have any effect on a child's loneliness, the instability hypothesis is not supported in terms of the father's situation (hypothesis 2a). With regard to the mother's household, we found evidence to support the instability hypothesis (hypothesis 2a): i.e., the presence of a co-residing new partner in the mother's household increased the child's feelings of loneliness. The change hypothesis (hypothesis $2 \mathrm{~b}$ ), which suggests that the availability of increased economic resources as a result of repartnering is of major importance for the mother, and that parental resources are less frequently distributed among children and their siblings in the mother's household - has to be rejected. By contrast, we conclude that the presence of a co-residing stepfather led to increased feelings of loneliness in the child, which might mean that the new relationship between the biological mother and the stepfather adversely affected the mother-child bond. These findings concerning the impact of family structure on the well-being of children are contrary to those in previous research by Bastaits et al. (2018) based on the same DiF dataset. They found that the child's well-being - measured using self-esteem, life satisfaction, and depression as outcome indicators was lower if the mother was single, in a LAT relationship, or had several relationships following her divorce; or if the father was sharing a household with a new partner. These opposite results clearly show that feelings of loneliness differ from other indicators of well-being, and are worth exploring.

With regard to living arrangements, we found that whether a child was in a joint physical custody arrangement had no effect on his/her feelings of loneliness. Thus, spending an equivalent amount of time in both the mother's and the father's household did not influence the child's loneliness in a positive or a negative way. Accordingly, our findings suggest that neither the instability hypothesis (hypothesis $3 a)$ nor the change hypothesis can be confirmed (hypothesis $3 \mathrm{~b}$ ). The child's age and gender, as well as the educational levels of both parents, did not have any significant effect on the child's feelings of loneliness. This finding is contrary to the results of Rotenberg's (1999) study, which reported differences between children and adolescents in their feelings of loneliness based on their family context.

Returning to the theoretical frameworks mentioned above, we note that the economic hardship theory suggests that compared with children living in a two-parent household, children living in a single-parent household are always exposed to relative deprivation because they rely on the economic resources of a single household, regardless of whether the adults in the household are the two biological parents or a biological parent and a stepparent. By comparison, the parental resource theory introduces an aspect of parenting that we can label as emotional capital, which is fed by a strong parent-child bond. The idea of emotional capital was already mentioned 
in early research on loneliness in children. The hypothesis that the emotional capital provided by the family contributes to children's feelings of loneliness was confirmed by Honig and Wittmer (1996), who found that children who were supported, nurtured, and cherished by their family were less likely to be rejected and were more likely to interact positively with their peers. Interpreting changing family structures in terms of a change in emotional capital shows that the change hypothesis on the impact of the presence of a stepparent in the parent's household (hypothesis 2 b) can be confirmed, especially if we consider a newly composed maternal family as involving a loss of parental resources that elicits feelings of loneliness in children, instead of as a gain of parental resources, as initially suggested in section "Hypotheses". Similarly, the increased feelings of loneliness evoked by an increasing number of paternal family transitions can be interpreted not only as an instable family structure (hypothesis 1a), but as a decrease in emotional capital, especially if we consider the fact that each time a father's relationship breaks up, the child's stepmother leaves the paternal household.

While this study contributes significantly to the existing literature on the wellbeing of children after divorce, it does have some limitations. First, we must recognize that only children of divorced people participated in the Divorce in Flanders (DiF) study. Although unmarried cohabitations are more likely to end in a break-up, and this family structure has become an increasingly accepted context for bringing up children, data on the children of separated couples are lacking in this study. Second, although more than 1000 children were interviewed in the DiF study, the analytical sample includes only 166 of them. This attrition was mainly due to nonresponse, as for most of these children only one parent participated in the study; whereas for the current research, triadic data were required. In addition to unit nonresponse, item non-response reduced the analytical sample size, as for some respondents, detailed and correct information on the partnership history as well as answers on the loneliness scale were missing. Third, and closely related to the second issue, is the limitation of the analytical model. Due to the small sample size, we did not have the opportunity to include mediating variables, such as parental involvement or the quality of the parent-child relationship. These variables could prove useful in explaining the mixed results for the different indicators of children's well-being. The last limitation concerns the measurement of the children's feelings of loneliness. All of the scales measuring loneliness in children focus primarily on social loneliness, as the items mainly refer to the respondent's wider social network of friends and classmates. Yet in the context of divorce, emotional loneliness, which refers to a bond with a specific person (such as a parent), could be more relevant. However, as we mentioned in the literature section, the existing studies on loneliness in children that primarily measured social loneliness emphasized that poor peer relationships during childhood is a contributory factor for social and emotional loneliness during adulthood, as lonely children may lack opportunities to interact with peers and to learn important skills that can improve their social interactions later in life.

Future research should investigate how feelings of loneliness experienced during childhood after a parental divorce affect people's relationship trajectories and/or 
subsequent feelings of loneliness during adulthood. Second, in addition to the effects of mediating variables such as parental involvement or parent-child relationship quality, the emotional and social loneliness of parents can be of major importance in understanding the impact of the characteristics of dual family life on loneliness in children. Research on the same DiF dataset has found evidence of an intergenerational effect of feelings of social loneliness; i.e., that parents who feel socially lonely are more likely to have lonely children (Heylen et al. 2013). Unfortunately, a gender-inclusive framework was lacking in this previous study. A study on feelings of loneliness in children adjusting to dual family life that also explores the loneliness of mothers and fathers as clarifying variables could shed light on the intergenerational transition of loneliness after divorce, separately for men and women and their children.

\section{References}

ADSEI. (2018). Algemene Directie Statistiek en Economische Informatie - Thematische Directie Samenleving. http://statbel.fgov.be/nl/statistieken/cijfers/bevolking. Accessed 25 May 2019.

Amato, P. R. (1993). Children's adjustment to divorce: Theories, hypotheses and empirical support. Journal of Marriage and the Family, 55(1), 23-38. https://doi.org/10.2307/352954.

Amato, P. R. (2000). The consequences of divorce for adults and children. Journal of Marriage and Family, 62(4), 1269-1287. https://doi.org/10.1111/j.1741-3737.2000.01269.x.

Amato, P. R. (2010). Research on divorce: Continuing trends and new developments. Journal of Marriage and Family, 72(3), 650-666. https://doi.org/10.1111/j.1741-3737.2010.00723.x.

Amato, P. R., \& Gillbreth, J. (1999). Nonresident fathers and children's well-being: A metaanalysis. Journal of Marriage and the Family, 61(3), 557-573. https://doi.org/10.2307/353560.

Amato, P. R., \& Keith, B. (1991). Parental divorce and the well-being of children: A meta-analysis. Psychological Bulletin, 110(1), 26-46. https://doi.org/10.1037/0033-2909.110.1.26.

Asher, S. R., Hymel, S., \& Renshaw, P. D. (1984). Loneliness in children. Child Development, 55(4), 1456-1464.

Audenaert, V. (2018). De samenstelling van het gezin - Fact Sheet Gezinsenquête [Constellation of the family - Fact Sheet Family Survey]. Brussels: Departement Welzijn, Volksgezondheid en Gezin, Vlaamse Overheid.

Bastaits, K., \& Pasteels, I. (2019). Is joint physical custody in the best interests of the child? Parentchild relationships and custodial arrangements. Journal of Social and Personal Relationships, Online First. https://doi.org/10.1177/2F0265407519838071.

Bastaits, K., Ponnet, K., \& Mortelmans, D. (2014). Do divorced fathers matter? The impact of parenting styles of divorced fathers on the well-being of the child. Journal of Divorce and Remarriage, 55(5), 1-27. https://doi.org/10.1080/10502556.2014.920682.

Bastaits, K., Pasteels, I., \& Mortelmans, D. (2018). How do post-divorce paternal and maternal family trajectories relate to adolescents' subjective well-being? Journal of Adolescence, 64, 98-108. https://doi.org/10.1016/j.adolescence.2018.02.005.

Baude, A., Pearson, J., \& Drapeau, S. (2016). Child adjustment in joint physical custody versus sole custody: A meta-analytic review. Journal of Divorce and Remarriage, 57(5), 338-360. https://doi.org/10.1080/10502556.2016.1185203.

Bauserman, R. (2002). Child adjustment in joint-custody versus sole-custody arrangements: A meta-analytic review. Journal of Family Psychology, 16(1), 91-102. https://doi. org/10.1037//0893-3200.16.1.91. 
Bauserman, R. (2012). A meta-analysis of parental satisfaction, adjustment and conflict in joint custody and sole custody following divorce. Journal of Divorce and Remarriage, 53(6), 464-488. https://doi.org/10.1080/10502556.2012.682901.

Brage, D., Meredith, W., \& Woodward, J. (1993). Correlates of loneliness among Midwestern adolescents. Adolescence, 28(111), 685-693.

Brown, T. A. (2006). Confirmatory factor analysis for applied research. New York: The Guilford Press. https://doi.org/10.1177/1094428108323758.

Bullock, J. (1993). Children's loneliness and their peer relationships with family and peers. Family Relations, 42(1), 46-49. https://doi.org/10.2307/584920.

Cassidy, J., \& Asher, S. R. (1992). Loneliness and peer relations in young children. Child Development, 63(2), 350-365. https://doi.org/10.1111/j.1467-8624.1992.tb01632.x.

Chipuer, H. M., Bramston, P., \& Pretty, G. (2003). Determinants of subjective quality of life among rural adolescents: A developmental perspective. Social Indicators Research, 61(1), 79-95. https://doi.org/10.1023/A:1021271831731.

Civitci, N., Civitci, A., \& Fiyakali, N. C. (2009). Loneliness and life satisfaction in adolescents with divorced and non-divorced parents. Educational Sciences: Theory and Practice, 9(2), 513-525.

Eurostat. (2015). Crude divorce rate, selected years, 1960-2015 (per 1000 persons). http:// ec.europa.eu/eurostat/statistics-explained/index.php/File:Crude_divorce_rate,_selected_ years,_1960-2015_(per_1_000_persons).png. Accessed 25 May 2019.

Fomby, P., \& Cherlin, A. J. (2007). Family instability and child well-being. American Sociological Review, 72(2), 181-204. https://doi.org/10.1177/000312240707200203.

Goossens, L., \& Marcoen, A. (1999). Relationships during adolescence: Constructive versus negative themes and relational dissatisfaction. Journal of Adolescence, 22(1), 65-79. https://doi. org/10.1006/jado.1998.0201.

Heylen, L., Pasteels, I., \& Mortelmans, D. (2013). Eenzaamheid over generaties heen? Eenzaamheid bij kinderen na de scheiding van hun ouders. [Loneliness across generations? Loneliness in children after the divorce of their parents]. In I. Pasteels, D. Mortelmans, P. Bracke, K. Matthijs, J. Van Bavel, \& C. Van Peer (Eds.), Scheiden in Meervoud (pp. 153-158). Leuven: Acco.

Honig, A. S., \& Wittmer, D. S. (1996). Helping children become more prosocial: Ideas for classrooms, families, schools, and communities. Young Children, 51(2), 62-70.

Houghton, S., Hattie, J., Carroll, A., Wood, L., \& Baffour, B. (2016). It hurts to be lonely! Loneliness and positive mental wellbeing in Australian rural and urban adolescents. Journal of Psychologists and Counsellors in Schools, 26(1), 52-67. https://doi.org/10.1017/jgc.2016.1.

$\mathrm{Hu}, \mathrm{L} ., \quad \&$ Bentler, P. (1999). Cutoff criteria for fit indices in covariance structure analysis: Conventional criteria versus new alternatives. Structural Equation Modeling, 6(1), 1-55. https://doi.org/10.1080/10705519909540118.

Koenig, L. J., Isaacs, A. M., \& Schwartz, J. A. (1994). Sex differences in adolescent depression and loneliness: Why are boys lonelier if girls are more depressed? Journal of Research in Personality, 28(1), 27-43. https://doi.org/10.1006/jrpe.1994.1004.

Ladd, G. W., Kochenderfer, B. J., \& Coleman, C. C. (1996). Friendship quality as a predictor of young children's early school adjustment. Child Development, 67(3), 1103-1118. https://doi. org/10.1111/j.1467-8624.1996.tb01785.x.

Langton, C. E., \& Berger, L. M. (2011). Family structure and adolescent physical health, behavior, and emotional well-being. Social Service Review, 85(3), 323-357. https://doi. org/10.1086/661922.

Lansford, J. E. (2009). Parental divorce and children's adjustment. Perspectives on Psychological Science, 4(2), 140-152. https://doi.org/10.1111/j.1745-6924.2009.01114.x.

Lau, S., Chan, D. W., \& Lau, P. S. (1999). Facets of loneliness and depression among Chinese children and adolescents. Journal of Social Psychology, 139(6), 713-729. https://doi. org/10.1080/00224549909598251. 
Lee, D., \& McLanahan, S. (2015). Family structure transitions and child development: Instability, selection and population heterogeneity. American Sociological Review, 80(4), 738-763. https:// doi.org/10.1177/0003122415592129.

Leon, K. (2003). Risk and protective factors in young children's adjustment to parental divorce: A review of the research. Family Relations, 52(3), 258-270. https://doi. org/10.1111/j.1741-3729.2003.00258.x.

Lodewijckx, E. (2005). Kinderen en scheiding bij hun ouders in het Vlaams Gewest. Een analyse op basis van Rijksregistergegevens [Children and the divorce of their parents in Flanders. An analysis of National Register data]. Brussels: Centrum voor Bevolkings- en Gezinsstudies, CBGS-Werkdocument, 7.

Maes, M., Van den Noortgate, W., Vanhalst, J., Beyers, W., \& Goossens, L. (2017). The children's loneliness scale: Factor structure and construct validity in Belgian children. Assessment, 24(2), 244-251. https://doi.org/10.1177/1073191115605177.

Magnuson, K., \& Berger, L. M. (2009). Family structure states and transitions: Associations with children's well-being during middle childhood. Journal of Marriage and Family, 71(3), 575-591. https://doi.org/10.1111/j.1741-3737.2009.00620.x.

Mortelmans, D., Pasteels, I., Bracke, P., Matthijs, K., Van Bavel, J., \& Van Peer, C. (2011). Divorce in Flanders. Codebook and questionnaires. Antwerp: University of Antwerp.

Muthén, L. K., \& Muthén, B. O. (2010). Mplus user's guide (6th ed.). Los Angeles: Muthén \& Muthén. https://doi.org/10.4236/sm.2012.24052.

Neels, K., Van Rossem, R., De Winter, T., \& Lauwereys, G. (2011). GGS Wave 1 Belgium. Sample design (GGP Belgium Paper Series, 1).

Neto, F. (1993). The satisfaction with life scale: Psychometrics properties in an adolescent sample. Journal of Youth and Adolescence, 22(2), 125-134. https://doi.org/10.1007/BF01536648.

Nielsen, L. (2011). Shared parenting after divorce: A review of shared residential parenting research. Journal of Divorce and Remarriage, 52(8), 586-609. https://doi.org/10.108 0/10502556.2011.619913.

Nielsen, L. (2013). Shared residential custody: Review of the research. American Journal of Family Law, 27(1), 123-137.

Nielsen, L. (2014). Shared physical custody: Summary of 40 studies on outcomes for children. Journal of Divorce and Remarriage, 55(8), 614-636. https://doi.org/10.1080/1050255 6.2014.965578.

Nielsen, L. (2015a). Shared physical custody: Does it benefit most children? Journal of the American Academy of Matrimonial Lawyers, 28, 79-138.

Nielsen, L. (2015b). Pop goes the woozle: Being misled by research on child custody and parenting plans. Journal of Divorce and Remarriage, 56(8), 595-633. https://doi.org/10.1080/1050255 6.2015.1092349.

Nielsen, L. (2017). Re-examining the research on parental conflict, coparenting, and custody arrangements. Psychology, Public Policy, and Law, 23(2), 211-231. https://doi.org/10.1037/ law0000109.

Pasteels, I. (2012, May 8). Nota ter voorbereiding van de Hoorzitting ontwerpdecreet houdende wijziging van het tarief op het recht op verdelingen en gelijkstaande overdrachten [Report in preparation of the public hearing regarding the draft decree on changing the tariff for divisions and equivalent transfers]. Vlaams Parlement.

Pasteels, I., \& Mortelmans, D. (2013). Gescheiden en dan? Herpartneren in Vlaanderen anno 2010 [Divorced, and then? Repartnering in Flanders in 2010]. Relaties en Nieuwe Gezinnen, 3(3), 1-66.

Pasteels, I., \& Mortelmans, D. (2015). Dyadic analysis of repartnering after divorce: Do children matter? Journal of Family Research, 10, 143-164. https://doi.org/10.2307/j.ctvddzmht.11.

Pasteels, I., Mortelmans, D., Bracke, P., Matthijs, K., Van Bavel, J., \& Van Peer, C. (2011). Divorce in Flanders: Methodology. Antwerp: University of Antwerp.

Pasteels, I., Lodewijckx, E., \& Mortelmans, D. (2013). Gezinstransities in de levensloop van mannen en vrouwen. [Family transitions in the life course of men and women]. In M. Corijn \& C. Van Peer (Eds.), Gezinstransities in Vlaanderen [Family transitions in Flanders] (pp. 37-72). Brussels: Studiedienst van de Vlaamse Regering. 
Qualter, P., Brown, S. L., Munn, P., \& Rotenberg, K. J. (2010). Childhood loneliness as a predictor of adolescent depressive symptoms: An 8-year longitudinal study. European Child \& Adolescent Psychiatry, 19(6), 493-501. https://doi.org/10.1007/s00787-009-0059-y.

Qualter, P., Vanhalst, J., Harris, R., Van Roekel, E., Lodder, G., Bangee, M., et al. (2015). Loneliness across the life span. Perspectives on Psychological Science, 10(2), 250-264. https:// doi.org/10.1177/1745691615568999.

Quay, L. (1992). Personal and family effects on loneliness. Journal of Applied Developmental Psychology, 13(1), 97-110. https://doi.org/10.1016/0193-3973(92)90008-6.

Robson, K. (2010). Changes in family structure and the well-being of British children: Evidence from a fifteen-year panel study. Child Indicators Research, 3(1), 65-83. https://doi.org/10.1007/ s12187-009-9057-3.

Rotenberg, K. J. (1999). Parental antecedents of children's loneliness. In K. J. Rotenberg \& S. Hymel (Eds.), Loneliness in childhood and adolescence (pp. 176-200). Cambridge: Cambridge University Press. https://doi.org/10.1017/CBO9780511551888.

Ryan, R. M., Markowitz, A. J., \& Claessens, A. (2015). Associations between family structure change and child behavior problems: The moderating effect of family income. Child Development, 86(1), 112-127. https://doi.org/10.1111/cdev.12283.

Sodermans, A. K., Vanassche, S., Matthijs, K., \& Swicegood, G. (2012). Measuring residential arrangements with the residential calendar. Journal of Family Issues, 35(1), 125-145. https:// doi.org/10.1177/0192513X12464947.

Thomson, E., \& McLanahan, S. S. (2012). Reflections on "Family structure and child well-being: Economic resources vs. parental socialization”. Social Forces, 91(1), 45-53. https://doi. org/10.1093/sf/sos119.

Thomson, E., Hanson, T. L., \& McLanahan, S. S. (1994). Family structure and child wellbeing: Economic resources vs. parental behaviors. Social Forces, 73(1), 221-242. https://doi. org/10.1093/sf/73.1.221.

Open Access This chapter is licensed under the terms of the Creative Commons Attribution 4.0 International License (http://creativecommons.org/licenses/by/4.0/), which permits use, sharing, adaptation, distribution and reproduction in any medium or format, as long as you give appropriate credit to the original author(s) and the source, provide a link to the Creative Commons license and indicate if changes were made.

The images or other third party material in this chapter are included in the chapter's Creative Commons license, unless indicated otherwise in a credit line to the material. If material is not included in the chapter's Creative Commons license and your intended use is not permitted by statutory regulation or exceeds the permitted use, you will need to obtain permission directly from the copyright holder.

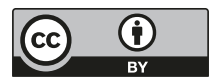

